Document downloaded from:

http://hdl.handle.net/10251/162356

This paper must be cited as:

Ripoll-Soler, C.; De-Miguel-Molina, M. (2019). Higher education mergers in Europe: a comparative study of the post-merger phase. Tertiary Education and Management. 25(3):255-271. https://doi.org/10.1007/s11233-019-09027-y

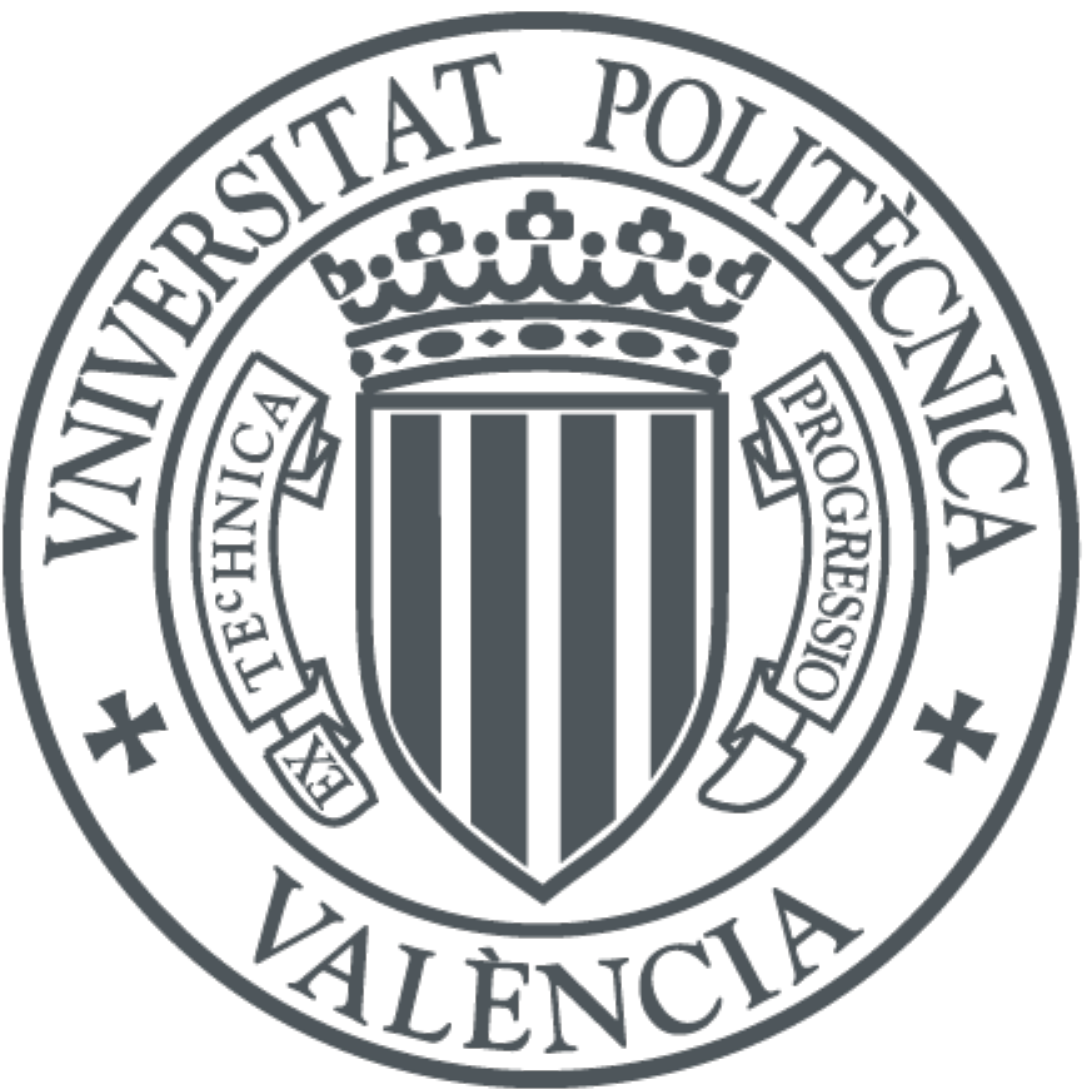

The final publication is available at

https://doi.org/10.1007/s11233-019-09027-y

Copyright Taylor \& Francis

Additional Information 


\title{
Higher education mergers in Europe: a comparative study of the post- merger phase
}

\author{
Carlos Ripoll-Soler and María de-Miguel-Molina \\ Universitat Politècnica de València, Spain \\ cripoll@upv.es
}

\begin{abstract}
The aim of this study is to compare the results of successful mergers in terms of ranking performance of the so called 'world-class' universities in a European Union context, with a view to identifying the challenges these universities face in their post-merger situation and strategies. After a content analysis, four themes emerged: crucial factors at the pre-merger phase to ensure a successful merger, the best actions to be performed at the merger phase to ensure a successful merger, the main challenges faced at the post-merger phase, and post-merger strategies in the last phase. Then, we analysed the institutional post-merger strategies to find differences between different mergers. Our research shows that in all cases there is a mix of various local and national/international factors that need to be analysed in the post-merger phase before a merger can be deemed to be 'successful' overall, and before the various dimensions of the global impact of the merger can be assessed.
\end{abstract}

Keywords: higher education, mergers, rankings, world-class universities, postmerger phase

\section{Introduction}

Mergers in higher education have been studied from different points of view, but the postmerger phase, also known as integration phase (Hall, Symes \& Luescher, 2004), has been 
the least studied area in this process, with only a few examples analysed in depth, except for South Africa (Barnard \& Van der Merwe, 2016). In Europe, the DEFINE project (Bennetot, Estermann \& Mason, 2014) offered recommendations to universities facing mergers.

The concept of institutional mergers in higher education is not a homogenous one. With a merger, two or more separate organisations form a unitary structure and overall management control comes under a single governing body and single chief executive (Harman \& Harman, 2008).

Higher education mergers have been used, among other reasons, as a means to improve international position and as a way to enter the group of the so-called 'worldclass universities' to gain more world visibility (Hazelkorn, 2007). Moreover, 'excellence in research underpins the idea of world-class research that is recognised by peers' (Altbach, 2015, p. 6). We can assume that cross-national competition is behind the desire to claim the status of a world-class university, sometimes without there really being any solid evidence to back up this claim (Wangenge-Ouma, 2010). Although internationalisation is difficult to define and criticism of international rankings has been widespread (Hazelkorn, Loukkola \& Zhang, 2014), internationalisation (Deschamps \& Lee, 2015) and world visibility (Docampo, Egret \& Cram, 2015), underlie the concept of world-class universities. There is a positive co-relation between world visibility and university rankings (Lee \& Park, 2012), like the Academic Ranking of World Universities (ARWU 2005-2015, University of Shanghai) or the QS University Ranking (QS company).

Despite the autonomy universities are supposed to have, governments set the guidelines by which institutions in their countries have to abide, so both government and universities play a role in mergers and have used mergers for different purposes. The first, 
especially in Europe, attempt (Walsh, 2014) to include their universities in the international top-100 league while increasing and improving academic productivity (Huisman, 2008; Slade, Ribando \& Fortner, 2016). The latter also promote mergers as a way to combat financial cuts by increasing efficiency, though some authors claim that efficiency gains 'may be a consequence of something other than the merger' (Johnes, 2014, p.485) and that ' the issues surrounding economies of scale in higher education are complex, and should not be considered from a single level perspective, or a single likely effect' (Patterson, 2000, p.268)

In this study, we compare the results of successful mergers involving world-class universities in the European Union that have subsequently led to an improvement in their position in higher education rankings (ARWU or QS), with a view to identifying the challenges these universities face in their post-merger situation. Therefore, we defined four research questions to analyse the post-merger situation in terms of enablers and results: RQ1 Why were these mergers successful?, RQ2 Were there any differences depending on their international position?, RQ3 How are they facing the post-merger phase?, and RQ4 Can we identify any differences in post-merger strategies in terms of their institutional model? Our conceptual world view was twofold, based on pragmatism, using mixed methods to study and compare different cases, and constructivism, exploring post-merger models.

\section{Literature review}

We used the Scopus database with Web of Science and Google Scholar. In an initial search, we obtained 1,394 results in Scopus using the keywords (merger AND higher education) OR (merger AND university) in the fields of social sciences. Then, we refined the search, focusing it on papers only related to higher education, and excluding journals which had no related scope. In this second search, we found also false negatives, thus 
bringing our final total to 81 papers.

As Figure 1 shows, the papers found in Scopus formed three groups from keyword co-occurrences. We used VOSviewer software to display this information with different figures: 'The colour of an item is determined by the cluster to which the item belongs' (Van Eck \& Waltman 2016, p. 4). A first group (A) focused on the impact and change that the merger represents (this could be the pre-merger phase); a second group (B) focused on the process of 'building' a new university and the role of the different institutions (merger phase); and a third group (C) focused on the results of the merger in terms of performance and research (post-merger phase).

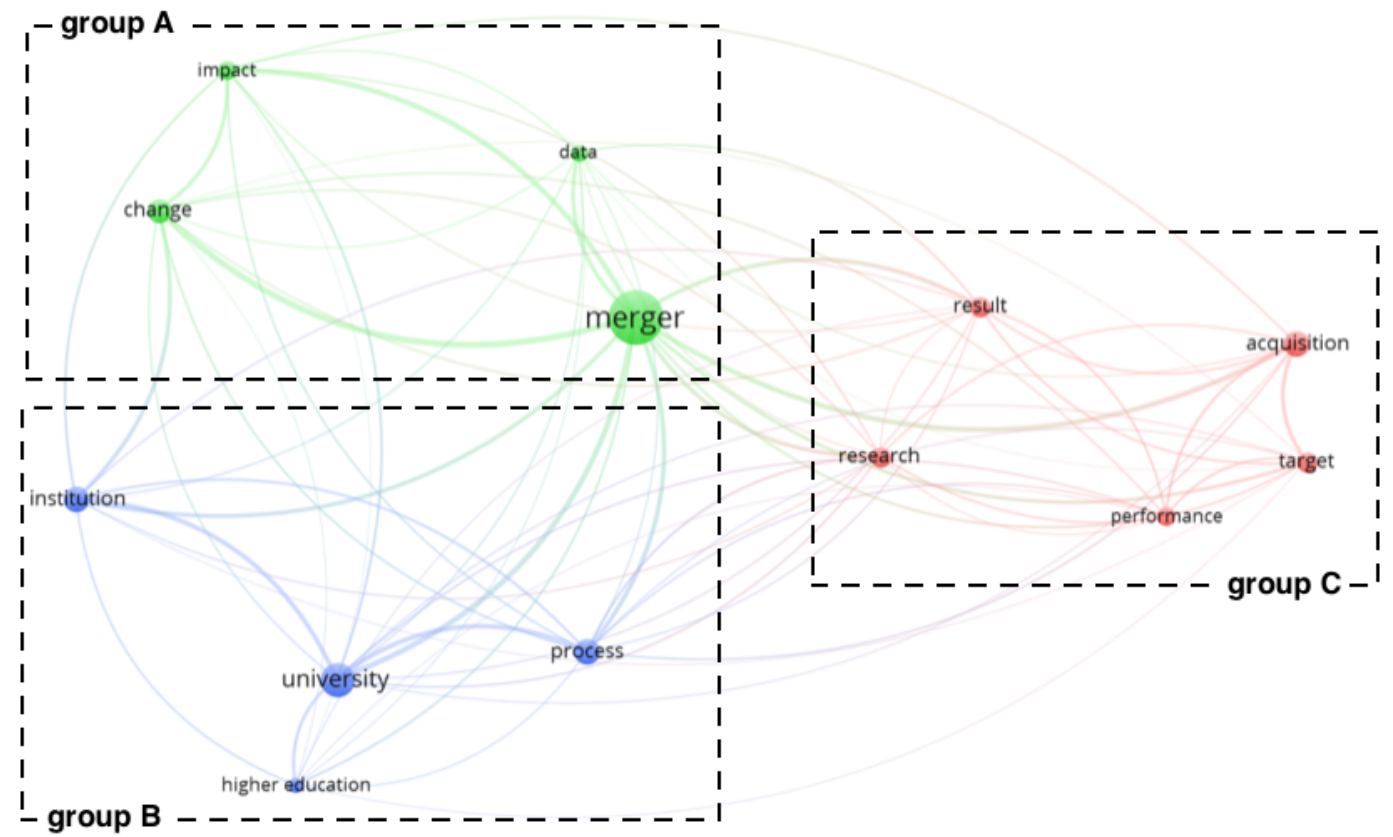

Figure 1. Paper network using Scopus Database and VOSviewer (Van Eck \& Waltman 2016).

The post-merger phase is a phase of evaluation, where the results can only be assessed after some years. According to the literature, mergers are complex processes that would need up to 10 years to achieve their full potential (Harman \& Harman, 2003). The 
pre-merger stage is especially stressful, due to the uncertainty it generates among employees if an active communication plan is not designed (Govender \& Rampersad, 2016).

The integration process requires the implementation of a new mission, vision, culture, identity (Puusa \& Kekäle, 2015), processes and procedures, and serious efforts to reduce bureaucracy as much as possible (Mael, 2014). In this phase, strong leadership is crucial to bring together all the previous cultures (Puusa \& Kekäle, 2013).

According to the literature, higher education mergers face critical cultural factors (Ripoll-Soler \& de-Miguel-Molina, 2013). These are related to attitudes of resistance (Aspara, Aula, Tienari \& Tikkanen, 2014), the perceived benefits for each party (Gleibs, Täuber, Viki \& Giessner, 2013), organisational change and destabilisation (Lawlor, 2013), future challenges (Mael, E. 2014), an increase in stress (Evans, 2015), redefining the academic profile (Ylijoki, 2014), and culture confrontations between the different parties (Aspara et al., 2014). In general, employees have positive and negative perceptions (soft factors) that have received less attention in literature (Lawlor, 2013).

One of the major challenges in the post-merger phase is to create a common academic culture. Case studies have shown that the crucial factors to generate this new culture in the merged institution involve a voluntary process of merging horizontal and complementary institutions, bilateral partnerships and a favourable context (Ripoll-Soler \& de-Miguel-Molina, 2013; 2014). Therefore, our first research question 'RQ1 Why were these mergers successful?', should be related to this question: Can the case studies explored be related to 'crucial factors' to create a common vision?

The DEFINE project (Beentot et al., 2014) presented some recommendations on how to obtain successful results, such as synergies with public authorities, giving precedence to the academic mission, exploring other alternatives, using change 
management methodologies, and internal and external communication. A comparison of these 'best actions' in the mergers under study can help us to respond to 'RQ2 Were there differences depending on their international position?'.

In short, according to the literature review, the 'main challenges' of a post-merger phase are to achieve a common culture, to tackle bureaucracy (Ripoll-Soler \& de-MiguelMolina, 2013), to adjust existing resources (Hidalgo-Hidalgo \& Valera, 2016), and to improve the range of academic courses on offer (Ylijoki, 2014) as well as the international research position. Moreover, physical location can also be a key factor (Lawlor, 2013) during pre-merger strategic deliberations, and one of the main reasons why 'in most cases mergers are with regional partners' (Frølich, Trondal, Caspersen \& Reymert, 2016, p. 12). These are the challenges that we must tackle with our third research question: 'RQ3 How are they facing the post-merger phase?'

\section{Method}

We followed a descriptive and deductive method, based on the results of the literature review, in order to compare cross-case studies of mergers in Europe. Our research design, based on the theoretical framework, took 'successful higher education mergers in Europe' as its unit of analysis, involving universities, and studying why they succeed and how they face future challenges (RQ4). We used an inductive approach to determine three institutional models according to the type of merging institutions ( $\mathrm{t} 1$ : university+university; $\mathrm{t} 2$ : specialised institution+specialised institution and $\mathrm{t} 3$ : university + specialised institution).

To gather the necessary data, we applied a triangulation model, using multiple data sources like strategic plans from each institution, university rankings, a literature review of the specific cases and in-depth interviews $(n=7)$ with managers involved in the new university model. We chose cross-case studies to compare some mergers, following 
Berg and Lune (2012), because it 'can reveal both the shared and the unique sense-making decisions' (p. 328).

Our population consisted of European Union universities where rankings were part of their strategic decisions. Our sample of institutions was composed of five universities, four of them were from ARWU: two universities (Strasbourg and Manchester) from ARWU 2015's Top 100 (from five 'hard' mergers whose ranking improved) plus two universities (Lisbon and Aalto) which ranked lower in ARWU 2015 but whose results improved (around 15). From the ARWU 2015 Top 100, we excluded the cases of two universities whose results remained the same or got worse: Edinburgh has ranked 47th since 2005 and Uppsala fell slightly to 61st. Therefore, we can observe that out of 22 European mergers (ARWU), only 7 appear in the ARWU Top 100: Strasbourg, Manchester, University College London, Copenhagen, Paris Sud XI, Edinburgh and Uppsala. As a control, we compared these universities with a case in which two specialised institutions (Centrale-Supélec) merged. This case did not appear in ARWU but improved its ranking slightly, entering the QS ranking in 2015 at 156 . The merged institution also participated in another federation Project called Paris Saclay.

Additionally, we gathered public information from the EU-backed DEFINE (Bennetot et al., 2014) project (although its results include other kinds of collaborations based on the CAM concept - collaborations, amalgamations and mergers), to check whether our cases followed the DEFINE recommendations. According to the DEFINE online tool, there were around 32 European mergers outside ARWU. Once again, we can see that out of a total of 54 mergers in Europe, only 22 of the merged universities appear in ARWU.

We identified seven key informants from the sample of institutions and performed seven semi-structured in-depth interviews (17 hours of interview time recorded and 
82,246 words transcribed) as part of the data triangulation. The interviews took place between October 2014 and May 2016. We can also say that the group of informants was homogenous (university managers) (Bonde, 2013). The sample was purposeful and had sufficient data saturation (Guetterman, 2016). Aalto University was the first case analysed, so we held two interviews in order to validate the semi-structured questionnaire. In the case of University of Strasbourg, we also did two interviews as the first interview was not long enough. Five of the participants were male and two were female.

To analyse the different documents and audios, we used content analysis. Berg and Lune (2012) defined this method as: "The analysis is designed to "code" the content as data in a form that can be used to address research questions' (pp. 349-350).

Four themes emerged: crucial factors $(\mathrm{C} 1)$ at the pre-merger phase to ensure a successful merger (RQ1), the best actions (C2) to be performed at the merger phase to ensure a successful merger (RQ2), the main challenges (C3) faced at the post-merger phase (RQ3), and post-merger strategies (C4) in the last phase. We grouped and coded the information as follows:

- C1-RQ1 Crucial factors: voluntary (1.1), horizontal and complementary (1.2), small number (1.3) and favourable context (1.4).

- C2-RQ2 Best actions: synergies with public authorities (2.1), precedence of academic mission (2.2), other alternatives explored (2.3), change management methodologies (2.4), internal communication (2.5) and external communication (2.6).

- C3-RQ3 Challenges: to achieve a common culture (3.1), to tackle bureaucracy (3.2), to adjust existing resources (3.3), to improve the range of academic courses on offer (3.4) and the university's international research position (3.5), and physical location (3.6). 
- C4-RQ4 Post-merger strategies related to the type of merger: strategies were defined following an inductive analysis of the interviews.

These categories were summarised in a first model (Table 1) which presents a typology of descriptors to compare three types of higher education mergers and the institutional model that emerges: university+university (t1), specialised institution + specialised institution (t2), and university+specialised institution (t3).

Table 1. Model to compare different types of university mergers

The model was used to prepare the interview protocol and carry out a content analysis of the interviews and the rest of documents. The interviews were structured around the following sections:

a) General overview of the merger process and its context.

b) University merger models.

c) Government influence.

d) Partners involved in the merger.

e) Creating the new culture.

f) Results of the merger.

\section{Results of the comparative analysis}

\section{Aalto University (Finland)}

Aalto University (AU) started to operate in 2010 (Aalto University, 2011). It was a t3 type merger, the result of a merger between one large university (Helsinki University of Technology), and two smaller ones (Helsinki School of Economics and the University of 
Arts and Design Helsinki). It was horizontal and complementary in terms of their different academic profiles with few overlaps.

The merger of Aalto was not voluntary. Instead, it was forced by a shift of paradigm. It was the answer to a new context where complexity was dominant and the competition for talent became international.

It is fundamental to first look at universities on a global scale, where there is increasing competition between universities all around the world. It is not so much about money, but rather about talent. (Informant 2)

Meanwhile universities were seen as 'being not good enough' (Informant 2) by government and industry, which were asking for a radical change to tackle key issues in the Finnish higher education system. Companies were also looking for better access to human capital. Though government and industry were not asking for a merger, they created the opportunity window for it to take place. Aalto's partners saw the opportunity and proposed a merger project based on a strong, multidisciplinary academic identity, financial and administrative freedom and separation from the state.

Many European universities have seen the case of Aalto as being an example of a successful merger, not because it moved into the top 100, but because it fulfilled most of the crucial factors for a merger. However, we found that the former universities faced drawbacks as a result of the merger, such as difficulties to agree upon common increased bureaucracy, as Mael (2014) also stated.

Though they were in ARWU and had had the same ranking (401-500) more or less from 2005-2015, there was a negative initial effect on their international research position, according to ARWU. 
Helsinki University of Technology was more research and publishing oriented than the two others... if you go for the general ranking the numbers will go down. (Informant 1)

Therefore, the new academic model was firstly based on attracting the best students and secondly on incorporating the best academics from all over the world with a tenure track system. This change is underway but will need at least 10 years before it is finished, which is in line with Harman \& Harman (2003):

After 10 years, you can roughly say that all the students that have come to Aalto don't know the former universities as such. (Informant 1)

\section{Centrale-Supélec (France)}

Centrale-Supélec (CS) is a t2 type merger, which happened in 2015 (CentraleSupélec, 2017) and is the result of merging two specialised institutions in France called 'Grandes Écoles': École Centrale and Supélec. They both had a very high educational profile but were looking to promote their research activities. A preliminary analysis conducted by École Centrale concluded that they needed a critical mass in order to have quality research and that research would be the best way to achieve international relevance and a means to attract more funds and to be present in rankings. Their result is quite satisfactory, and the merged institution ranks 140th in QS 2019, though has a better standing in engineering (51-100).

The merger between Centrale and Supélec was voluntary. Government approved the merger although it did not provide many economic incentives. It was horizontal and complementary with teaching profiles that did not overlap as there were only two institutions and both had very good connections with industry. They complied with almost all of the 'crucial factors', though the context, which was not necessarily 
'unfavourable', lacked the necessary pressure and economic incentives to move things along faster:

The directors from both Centrale and Supélec appointed an independent project leader to make them agree on the project... the pre-merger phase... lasted more than 4 years. This is definitely too long. (Informant 3 )

As Aspara (2014) remarks, generating a common culture is very difficult, at least in the initial years of merger implementation:

You need to make big efforts to get people to work together, get to know each other, share spaces, build a new culture... Now we are merging the core activities: teaching and research. (Informant 3)

At the moment, apart from building a common culture, Centrale-Supélec faces two main challenges: their location and their participation in 'Paris Saclay' (French Ministry of National Education, Higher Education and Research, 2014), where we detected an scenario almost the opposite to that of Centrale-Supélec, lacking most of the crucial factors, except for the government pushing integration by injecting additional resources into the project.

\section{The University of Lisbon (Portugal)}

In order to increase their international profile, develop their academic profile and achieve higher positions in rankings, the University of Lisbon and the Technical University of Lisbon, two universities each with about 25,000 students with complementary profiles, merged to create the University of Lisbon (UL), a t1 type merger, in 2013 (Portuguese Ministry of Science and Education, 2013; Universidade de Lisboa, 2014). They merged voluntarily, with few overlaps, as a reaction to the economic crisis in Portugal, that had 'a significant impact on the resources available for education, making that the HEI 
restructures its organization in consequence of the austerity measures' (David, Abreu, Segura, Formigoni \& Mantovani, 2015, p. 6061). There were historical reasons involved in the operation.

The main characteristic of this merger was the autonomy of the different schools, making the merger process easier because no restructuring of schools was required thus leaving power relations mainly as they had been:

One of the things discussed during the merger process was that there should be a big autonomy within the hands of the Schools. (Informant 4)

The main aim of the merger process was to reduce the size of the rectorate and central services and to channel human resources to the schools, building a new central structure and regulations:

A huge part of my work during the first two years has been mainly bureaucratic, to make regulations for everything. (Informant 4)

This is in line with Mael (2014), who discussed tackling bureaucracy, and Hidalgo-Hidalgo and Valera (2016), who stated the need for adjusting existing resources as a consequence of a merger process.

The merger centred on improving its research position by being a larger institution, and increasing the number of new multidisciplinary approaches by having more disciplines in the same institution. There was almost no mention of any teaching restructuring beyond some changes in doctoral training. Their strongest action before and during the merger was internal communication, a topic also discussed by Bennetot et al. (2014), carrying out negotiations with all the personnel.

You can't take organisational decisions. They have to be postponed to the postmerger. (Informant 4) 
In terms of rankings, they focused on improving their ARWU position, which seems to have been achieved. In 2018, it ranked in the 151-200 bracket (ARWU 2018). The role of other stakeholders in this process was very low key. Companies had no role in the process and the government did not provide any economic incentives.

\section{The University of Manchester (United Kingdom)}

The University of Manchester (UM), a t3 type merger, is the result of merging a small, highly specialised university, the University of Manchester Institute of Science and Technology (UMIST) and the Victoria University of Manchester (VUM), a large generalist university. Historically, both institutions had strong links until 1994 when UMIST obtained its own award degree powers. The new university started to operate as such in 2004 (Abendstern, 2007). A joint working group, made up of four members from each institution, was set up by the heads of the two universities and was independently chaired by a former executive and government adviser. They analysed the different types of partnerships available and ended up opting for the dissolution of the two existing universities and the creation of a single new one. This is in line with the recommendations made by Bennetot et al. (2014).

This merger was the reaction to achieve world-class status to compete with the very best universities (Georghiou, 2015) by means of rankings, fund raising and internationalisation. In the case of UMIST, it was also a survival strategy. The influence of industry in the city is almost inexistent nowadays. Regional government reacted by providing additional funding for the new institution but did not promote any other changes to support the merger.

Strong leadership, cooperation and the precedence of an academic mission was fundamental for the success of this merger. Though they first focused on the academic 
part, they also followed a structural approach to diminish administrative redundancies two years after the merger. Cultural shocks were quite relevant in this case:

There were probably three cultures... there were the people on either side that were not really very sure or not really very happy. Then there were those who were saying "well this is a new opportunity, let's go for it". And those against it, trying to understand something new by oversimplifying. (Informant 5)

It was very clear that for these two universities the main objective was to be in the top 100. In this sense, they are the best example of success as in 2018 they ranked 34th on ARWU 2018:

The Shanghai Jiao Tong index doesn't change the weightings so rapidly from year to year as the others, so it is a more consistent indicator. (Informant 5)

In 2015, the University of Manchester had around 35,800 students (ARWU 2015). Therefore, it is still within the limit of what we found to be the optimal size of around 30,000 (Ripoll-Soler \& de-Miguel-Molina, 2014).

\section{The University of Strasbourg (France)}

Three universities merged in 2009 on a t1 type merger: University Louis Pasteur, University Robert Schuman and University Marc Bloch, producing the 'Renaissance' of the former University of Strasbourg (US) (Musselin \& Dif-Pradalier, 2014) that had been split into three different universities after the 1968 student protests in France. It was a long process as different cultures were involved:

We needed five years until the impact of the merger could be considered a success. (Informant 6)

Though informant 6 says 'it was voluntary', the Government played an important role in pushing some initiatives to improve the performance of French universities in 
ARWU (Docampo, Egret \& Cram, 2014). The vision of the new university itself was not so clear. There was a lack of internal communication with the academics and administrative personnel during the merger.

In 2015, the new university had around 42,000 students (ARWU 2015). That is, it is a large university, compared to those in the top 100. After six years, some objectives have been reached but no new organisational structure has emerged for the university. There were clear overlaps between the three former universities and no new academic profile has been defined, as discussed by Ylijoki (2014). Cultural roots are still difficult to handle and, in line with Lawlor (2013), people still feel quite upset about the merger:

Researchers do work with other institutions and when they have results they mention their research centre but they do not mention they are part of the University of Strasbourg. (Informant 6)

From 2005-2015, the University's ARWU position improved and it moved into the top 100 , but since 2016 its position decreased on the ranking to the $101-150$ bracket (ARWU 2018). Moreover, cultural resistance and the lack of strong leadership are not helping to give the university the necessary power to move forward:

It needs a core team of people who are going stick together whatever. (Informant 7)

\section{Revision}

After an inductive content analysis of all the materials, we found a new crucial factor for RQ1 related to decentralisation (1.5), another best action for RQ2 about connections with industry (2.7) and six potential merger strategies related to size (4.1), rankings (4.2), support (4.3), funding (4.4), orientation (4.5) and new business model (4.6). An updated version of the first model is shown in Table 2 including the new insights. We found the comparative results shown in Table 3. 
Table 2. Model to compare different types of university mergers (revised).

Table 3. Comparative analysis of the results.

The co-occurrences in the content analysis of the interviews (Figure 2) enabled us to confirm some of the categories in our model:

- The importance of internal communication (Bennetot et al., 2014; Evans, 2015; Lawlor, 2013) to discuss the merger, with strong leadership and a robust team being crucial (cluster 1).

- Conversely, external communication mainly involves government and ministries (Bennetot et al., 2014), but also industry (cluster 2). In this case, students are normally seen as stakeholders rather than participants (with few exceptions).

- Finally, the post-merger models face a major challenge: people and culture (Lawlor, 2013) (cluster 3). However, this is also influenced by the type of merger, with a special focus on mergers between two different institutions (university and specialised institution) or when one of them wants to maintain its status (specialised institution with another specialised institution). 


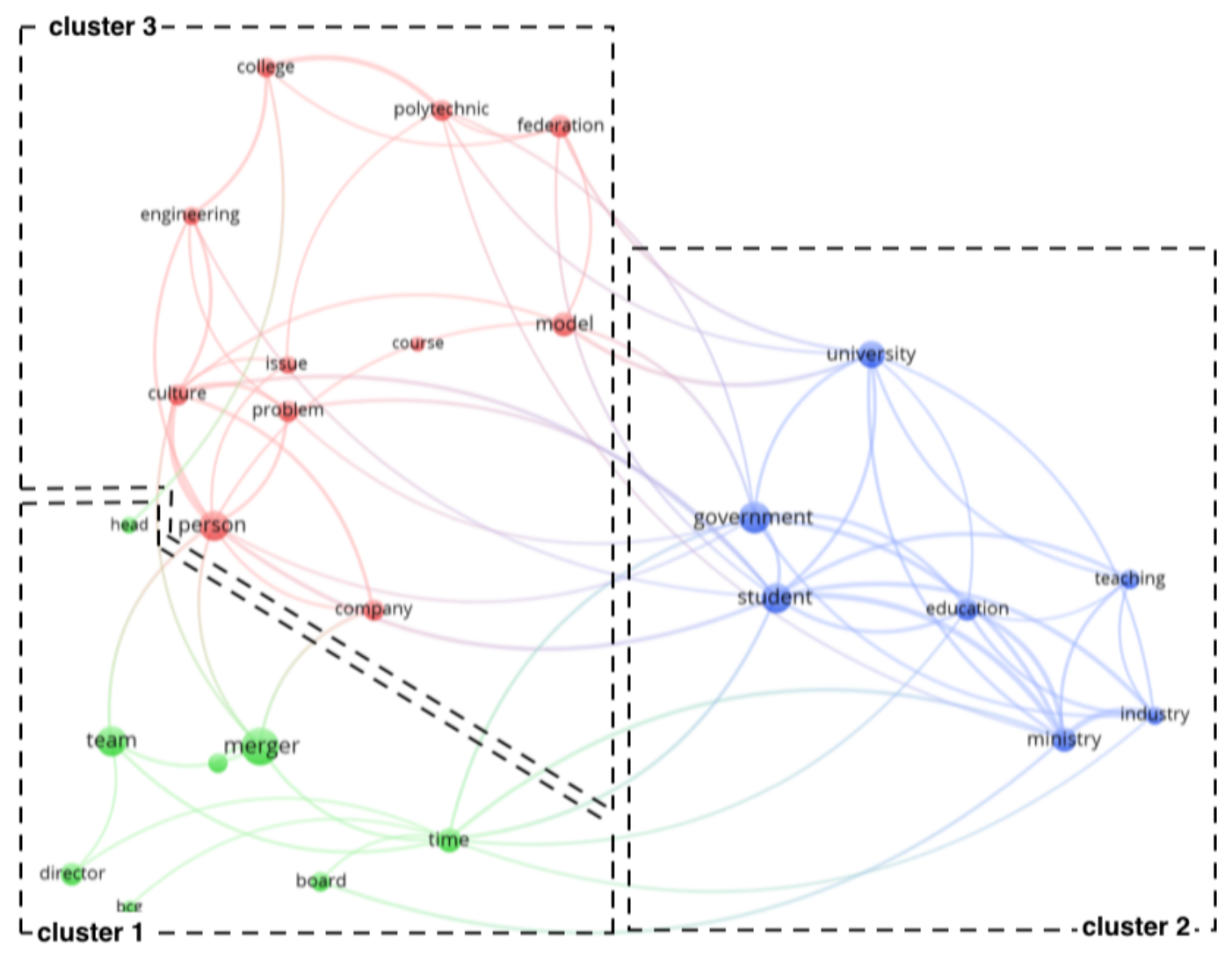

Figure 1. Interview network using VOSviewer (Van Eck \& Waltman 2016).

\section{Concluding discussion}

We first detected that only Aalto University admitted that the merger could be a reaction to external pressure. The rest claim that the mergers were totally voluntary given that nobody can force them to do so, according to the law and principle of autonomy. Governments in Europe cannot force universities to merge, but they can create a favourable context providing incentives (Goedegebuure, 2012; Harman \& Meek, 2002; Hazelkorn, 2007; Ripoll-Soler \& de-Miguel-Molina, 2013; 2014). The pressure to merge is even greater if industry also cooperates, or even the press (Salmi \& Saroyan, 2007). Nonetheless, as Frølich, et al. (2016) say, 'most of the merger processes are done in the sequence of voluntary mergers before enforced mergers are imposed' (p. 5). 
We found that, if the university is strongly decentralised, as is the case of Lisbon, the process itself becomes very smooth and all the efforts concentrate on merging central services and channelling excess capacity to the schools. The challenges are considerably reduced, with no need to achieve a common culture because the predominant cultures are the ones that prevail in the schools. These cultures are linked with academic autonomy, a value that remains strong even in a stratified higher education system (Henkel, 2005). According to Informant 2, 'If you develop an administrative culture that is dominated by one of the previous cultures it has negative effects'. We consider it should be necessary to assess to what extent this finding would be useful to institutional decision-making.

In terms of leadership we found that, while mergers require strong leadership (Chipunza \& Gwarinda, 2010), not all merged universities provide this:

We go in and we try to be as open as possible because we want to do this together... and it needs a huge dose of humility and generosity. (Informant 6)

Though some authors like Kyvik (1995) or Mao, Du \& Lia (2009) argue that there is no direct relationship between the size of an institution and its scientific productivity, the case of Lisbon is closely connected with the size effect of merging two institutions. Nonetheless, its performance in publications and impact on the ranking is very low when compared to Manchester which, with almost the same number of publications in 2005 , had moved up the ranking much further than Lisbon in 2015. To be identified with the main city they are in also seems to be very important for the majority of universities, but not for the specialised ones.

Only Aalto excluded rankings as part of the main rationale for the merger but, as shown on ARWU 2018, they are improving their position year after year. This finding supports the idea of comprehensive reorganisation of the university to build a truly new 
institution by putting almost all of the potential best actions into practice and giving precedence to the academic mission (Bennetot et al., 2014):

That means that you are among the best universities but not in terms of specific numbers. World-class is a statement of excellence in all aspects. (Informant 2)

The only case that underperforms in rankings is the University of Strasbourg, which has the least crucial factors (only voluntary and complementary) presented in this study, some of which is backed up by other authors like Bennetot et al. (2014). Though it has been positively assessed over the last ten-year period, it underperformed considerably at the time of the merger and in the 2018 results.

According to our comparative analysis, the merger that has performed best in ARWU is the University of Manchester and the merger that has performed worst is the University of Strasbourg. This is in accordance with the most recent ARWU 2018, in which Manchester's ranking improved while Strasbourg lost ground. As Table 4 shows, only the University of Strasbourg has not improved its ranking since the merger.

Table 4. Comparative performance in the international ranking 2005-2015-2018.

Source: Own source. WoS: Web of Science publications.

We consider that working on best actions helps to reduce uncertainty in the environment, implying the institution has to face fewer challenges. Hence, institutions implementing the largest number of best actions had less challenges to face than their counterparts. A wider quantitative analysis would be a solid base to confirm these insights.

Like mergers that take place in other types of entities, institutional mergers in higher education are always special cases that bear the footprint of those who initiate and implement them, as well as the distinctive features of their location, the starting position 
of the entities involved and the ambitions that guide them. The key factor determining relative success or failure is human attitudes and behaviour, in particular in terms of the ability of individuals and groups to anticipate, accept and shape the necessary cultural change required by mergers.

While all these aspects need to be dealt with in the pre-merger and implementation phase, they are of particular relevance in the post-merger period, given the patterns that change over time after the formal merger date so 'a long-term perspective is needed to ensure an understanding of institutional trajectories' (Fumasoli, Pinheiro \& Stensaker, 2015, p. 23).

This paper provides a structured method for analysing merger processes in their different phases. We provide a selection of crucial factors, best actions and main challenges based on the literature review and on inductive content analysis. Our main contribution is a set of post-merger strategies, that we consider will help in overcoming the absence of practical approaches on how to develop the institution once the merger is done (Frølich et al., 2016). We believe that our observations can be of great help for decision makers in universities and all those in national or regional government considering mergers.

Our research has shown that in all cases there is a mix of various local and national/international factors that need to be analysed in the post-merger phase before a merger can be deemed to be an overall success, and the various dimensions of the overall impact of the merger can be assessed. We are also fully aware that as time goes by after a merger the balance of benefits and problems may shift in one direction or another since the post-merger phase has a starting point but no end, and corrective measures may or may not be taken in order to address ongoing or new difficulties faced by the merged 
institution. From this perspective, it would be highly interesting to re-evaluate the cases reviewed in this article in another five to ten years.

\section{References}

Aalto University (2011). Aalto's Year 2010 in Review. Retrieved from https://www.aalto.fi/sites/g/files/flghsv161/files/201809/aalto_university_aalto_2010_in_review.pdf

Abendstern, M. (2007). Project Unity. In B. Pullan (ed.). A Portrait of the University of Manchester (pp. 68-71). London: Third Millennium Publishing

Altbach, P. (2015). The costs and benefits of world-class universities. International Higher Education, 33, 5-8.

Aspara, J., Aula, H.M., Tienari, J. \& Tikkanen, H. (2014). Struggles in organisational attempts to adopt new branding logics: the case of a marketizing university. Consumption Markets and Culture, 17(6), 522-552.

Barnard, Z. \& Van der Merwe, D. (2016). Innovative management for organizational sustainability in higher education. International Journal of Sustainability in Higher Education, 17(2), 208-227.

Bennetot, E., Estermann, T. \& Mason, P. (2014). The DEFINE project: University mergers in Europe (Thematic report No. 2). Brussels: European University Association. Retrieved from http://www.eua.be/Libraries/define/2definethematic-report-2-university-mergers-in-europe_final.pdf?sfvrsn=0

Berg, B.L. \& Lune, H. (2012). Qualitative Research Methods for the Social Sciences. New Jersey: Pearson Education.

Bonde, D. (2013). Qualitative interviews: when enough is enough. Research by Design. Retrived from http://www.raptureconsulting.com/uploads/2/4/3/8/24380515/how_many_qualit ative_interviews.pdf 
CentralSupélec (2017). Nouvelle École, noveaux codes. Retrieved from http://www.centralesupelec.fr/sites/default/files/livret-strategiquecentralesupelec.pdf

Chipunza, C. \& Gwarinda, S.A. (2010). Transformational leadership in merging higher education institutions: A case study. SA Journal of Human Resource Management, 8(1), 195-205

David, F., Abreu, R., Segura, L., Formigoni, H. \& Mantovani, F. (2015, March). Impact of the economic crisis on the higher education: the case of Portugal. In L. Gómez, A. López and I. Candel (eds.). INTED 2015 Proceedings of the $9^{\text {th }}$ International Technology, Education and Development Conference (pp. 6053-6066). Madrid (Spain): IATED Academy.

Deschamps, E. \& Lee, J. J. (2014). Internationalization as Mergers and Acquisitions Senior International Officers' Entrepreneurial Strategies and Activities in Public Universities. Journal of Studies in International Education, 19(2), 122-139.

Docampo, D., Egret, D. \& Cram, L. (2015). The effect of university mergers on the Shanghai ranking. Scientometrics, 104(1), 175-191.

Docampo, D., Egret, D. \& Cram, L. (2014). French COMUEs and the Shanghai Ranking (DEC Technical Report). Retrieved from https://www.researchgate.net/publication/266557914_French_COMUEs_and_th e_Shanghai_Ranking/download

Evans, L. (2015). The worst of times? A tale of two higher education institutions in France: their merger and its impact on staff working lives. Studies in Higher Education, 42(9), 1699-1717.

French Ministry of National Education, Higher Education and Research (2014). Décret $n^{o}$ 2014-1674. Journal Officiel de la République Française. https://www.legifrance.gouv.fr/eli/decret/2014/12/29/MENS1425099D/jo

Frølich, N., Trondal, J., Caspersen, J. \& Reymert, I. (2016) Managing mergers governancing institutional integration. Tertiary Education and Management, $22(3), 231-248$

Fumasoli, T., Pinheiro, R. \& Stensaker, B. (2015) Handling Uncertainty of Strategic Ambitions-The Use of Organizational Identity as a Risk-Reducing Device. International Journal of Public Administration, 38(13-14), 1030-1040

Georghiou, L. (2015). Strategy to Join the Elite: Merger and the 2015 Agenda at the University of Manchester - An Update. In A. Curaj, L. Georghiou, J.C. Harper 
and E. Egron-Polak (eds.), Mergers and Alliances in Higher Education (pp. 205220). Springer.

Gleibs, I.H., Täuber, S., Viki, G.T. \& Giessner, S.R. (2013). When what we get is not what we want: the roles of implemented versus desired merger patterns in support for mergers. Social Psychology, 44(3), 177-190.

Goedegebuure, L. (2012). Mergers and more: the changing tertiary education landscape in the 21st century (HEIK Working Paper Series). Oslo: Faculty of Educational Sciences. University of Oslo

Govender, V. \& Rampersad, R. (2016). Change management in the higher education landscape: A case of the transition process at a South African University. Risk Governance and Control: Financial Markets and Institutions, 6(1), 43-51.

Guetterman, T.C. (2016). What distinguishes a novice from an expert mixed methods researcher? Quality \& Quantity, 51(1), 377-398.

Hall, M., Symes, A. \& Luescher, T. (2004). The Governance of Merger in South African Higher Education. Research report prepared for the Council on Higher Education. Pretoria: CHE.

Harman, G. \& Harman, K. (2003). Institutional Mergers in Higher Education: Lessons from International Experience. Tertiary Education and Management, 9(1), 29-44.

Harman, G. \& Harman, K. (2008). Strategic Mergers of Strong Institutions to Enhance Competitive Advantage. Higher Education Policy, 21(1), 99-121.

Harman, K. \& Meek, V.L. (2002). Introduction to special issue: Merger revisited: international perspectives on mergers in higher education. Higher Education, 44(1), 1-4.

Hazelkorn, E. (2007). The impact of league tables and ranking systems on higher education decision making. Higher Education Management and Policy, 19(2), 87110.

Hazelkorn, E., Loukkola, T. \& Zhang, Th. (2014). Rankings in Institutional Strategies and Processes: Impact or Illusion?. Brussels: European University Association. Retrieved from http://www.eua.be/Libraries/Publications_homepage_list/EUA_RISP_Publicatio n.sfl b.ashx

Henkel, M. (2005). Academic identity and autonomy in a changing policy environment. Higher Education, 49(1-2), 155-176 
Hidalgo-Hidalgo, M. \& Valera, G. (2016). University merging process: A guideline proposal for excellence-enhancing. The B.E. Journal of Economic Analysis and Policy, 16(3), 1359-1386.

Huisman, J. (2008). World-class universities. Higher Education Policy, 21(1), 1-4.

Johnes, J. (2014). Efficiency and mergers in English higher education 1996/97 to 2008/9: Parametric and non-parametric estimation of the multi-input multi-output distance function. The Manchester School, 82(4), 465-487.

Kyvik, S. (1995). Are big university departments better than small ones?. Higher Education, 30(3), 295-304.

Lawlor, J. (2013). Employee Perspectives on the Post-integration Stage of a Micromerger. Personnel Review, 42(6), 704-723.

Lee, M. \& Park H.W. (2012). Exploring the web visibility of world-class universities. Scientometrics, 90(1), 201-218

Mael, E. (2014). When one plus one remains one the challenges and triumphs of merging two university libraries. Library Resources \& Technical Services, 58(4), 265-278.

Mao, Y., Du, Y. \& Lia, J. (2009). The Effects of University Mergers in China since 1990s. International Journal of Educational Management, 23(1), 19-33.

Musselin, C. \& Dif-Pradalier, M. (2014). Quand la fusion s'impose : la (re) naissance de l’Université de Strasbourg. Revue Française de Sociologie, 2(55), 285-318.

Patterson, G. (2000). Findings on economies of scale in higher education: implications for strategies of merger and alliance. Tertiary Education and Management, 6(4), 259-269

Portuguese Ministry of Science and Education (2013). Decreto-Lei $n .^{\circ}$ 266-E/2012. Diario da República. Retrieved from https://dre.pt/application/conteudo/632432

Puusa, A. \& Kekäle, J. (2013). Commitment in the Context of a Merger. Tertiary Education and Management, 19(3), 205-218.

Puusa, A. \& Kekäle, J. (2015). Feelings over facts - a university merger brings organisational identity to the forefront. Journal of Higher Education Policy and Management, 37(4), 432-446.

Ripoll-Soler, C. \& de-Miguel-Molina, M. (2013). Las fusiones universitarias: análisis de contenido de sus tipologías y los factores que pueden determinar su éxito o fracaso. Una revisión de la literatura. Revista de Educación, extraordinario, 313337. 
Ripoll-Soler, C. \& de-Miguel-Molina, M. (2014). Are mergers a win-win strategic model? A content analysis of inter-institutional collaboration between higher education institutions. Tertiary Education and Management, 20(1), 44-56.

Salmi, J. \& Saroyan, A. (2007). League tables as policy instruments: uses and misuses. Higher Education Management and Policy, 19(2), 31-68.

Slade, C.P., Ribando, S.J. \& Fortner, C.K. (2016). Faculty research following merger: a job stress and social identity theory perspective. Scientometrics, 107(1), 71-89.

Universidade de Lisboa (2014). Relatório de gestao e de atividades 2013. Retrieved from https://www.ulisboa.pt/sites/ulisboa.pt/files/documents/files/2013.pdf

Van Eck, N.J. and Waltman, L. (2016). Manual for VOSviewer version 1.6.5. CWTS, Leiden: Universiteit Leiden.

Walsh, J. (2014). 'The problem of Trinity College Dublin': a historical perspective on rationalisation in higher education in Ireland. Irish Educational Studies, 33(1), 519.

Wangenge-Ouma, G. (2010). Universities and the mobilization of claims of excellence for competitive advantage. Higher Education, 59(6), 749-764.

Ylijoki, O.H. (2014). University Under Structural Reform: A Micro-Level Perspective. Minerva, 52(1), 55-75. 
Table 1. Model to compare different types of university mergers

\begin{tabular}{|c|c|c|c|}
\hline Group & Phase & Factor & Source \\
\hline \multirow{4}{*}{$\begin{array}{l}\text { C1-RQ1: } \\
\text { Crucial factors }\end{array}$} & \multirow{4}{*}{ Pre-merger } & 1.1: Voluntary & $\begin{array}{l}\text { Ripoll \& De Miguel, } \\
\text { 2013; } 2014\end{array}$ \\
\hline & & $\begin{array}{l}\text { 1.2: Horizontal and } \\
\text { complementary }\end{array}$ & $\begin{array}{l}\text { Ripoll \& De Miguel, } \\
\text { 2013; } 2014\end{array}$ \\
\hline & & 1.3: Small number & $\begin{array}{l}\text { Ripoll \& De Miguel, } \\
\text { 2013; } 2014 \\
\text { Gleibs, et al., } 2013\end{array}$ \\
\hline & & 1.4: Favourable context & $\begin{array}{l}\text { Ripoll \& De Miguel, } \\
\text { 2013; } 2014 \\
\text { Harman \& Harman, } 2003\end{array}$ \\
\hline \multirow{4}{*}{$\begin{array}{l}\text { C2-RQ2: Best } \\
\text { actions }\end{array}$} & \multirow{4}{*}{ Merger } & $\begin{array}{l}\text { 2.1: Synergies with } \\
\text { public authorities }\end{array}$ & $\begin{array}{l}\text { Hazelkorn, } 2007 \\
\text { Bennetot et al, } 2014 \\
\text { Walsh, } 2014\end{array}$ \\
\hline & & $\begin{array}{l}\text { 2.2: Precedence of } \\
\text { academic mission }\end{array}$ & $\begin{array}{l}\text { Slade et al., } 2016 \\
\text { Huisman, } 2008 \\
\text { Ylijoki, } 2014 \\
\text { Bennetot et al, } 2014\end{array}$ \\
\hline & & $\begin{array}{l}\text { 2.3: Other alternatives } \\
\text { explored }\end{array}$ & Bennetot et al, 2014 \\
\hline & & $\begin{array}{l}\text { 2.4: Change } \\
\text { management } \\
\text { methodologies }\end{array}$ & $\begin{array}{l}\text { Lawlor, } 2013 \\
\text { Bennetot et al, } 2014\end{array}$ \\
\hline
\end{tabular}




\begin{tabular}{|c|c|c|c|}
\hline & & $\begin{array}{l}\text { 2.5: Internal } \\
\text { communication }\end{array}$ & $\begin{array}{l}\text { Evans, } 2015 \\
\text { Lawlor, } 2013 \\
\text { Bennetot et al, } 2014\end{array}$ \\
\hline & & $\begin{array}{l}\text { 2.6: External } \\
\text { communication }\end{array}$ & Bennetot et al, 2014 \\
\hline \multirow{6}{*}{$\begin{array}{l}\text { C3-RQ3: Main } \\
\text { challenges }\end{array}$} & \multirow{6}{*}{ Post-merger } & $\begin{array}{l}\text { 3.1: Achieve a common } \\
\text { culture }\end{array}$ & $\begin{array}{l}\text { Puusa \& Kekäle, } 2015 \\
\text { Aspara et al., } 2014 \\
\text { Ripoll \& De Miguel, } \\
\text { 2013; } 2014\end{array}$ \\
\hline & & 3.2: Tackle bureaucracy & $\begin{array}{l}\text { Ripoll \& De Miguel, } \\
\text { 2013; } 2014 \\
\text { Mael, E. } 2014\end{array}$ \\
\hline & & $\begin{array}{l}\text { 3.3: To adjust existing } \\
\text { resources }\end{array}$ & $\begin{array}{l}\text { Johnes, } 2014 \\
\text { Hidalgo-Hidalgo \& } \\
\text { Valera, } 2016\end{array}$ \\
\hline & & $\begin{array}{l}\text { 3.4: To improve the } \\
\text { range of academic } \\
\text { courses on offer }\end{array}$ & $\begin{array}{l}\text { Hidalgo-Hidalgo \& } \\
\text { Valera, } 2016\end{array}$ \\
\hline & & $\begin{array}{l}\text { 3.5: To improve } \\
\text { international research } \\
\text { position }\end{array}$ & $\begin{array}{l}\text { Altbach, } 2015 \\
\text { Wangenge-Ouma, } 2010 \\
\text { Deschamps \& Lee, } 2014 \\
\text { Docampo et al., } 2015 \\
\text { Lee \& Park, } 2012\end{array}$ \\
\hline & & 3.6: Physical location & $\begin{array}{l}\text { Lawlor, } 2013 \\
\text { Frølich, N. et al., } 2016\end{array}$ \\
\hline
\end{tabular}



Table 2. Model to compare different types of university mergers (revised)

\begin{tabular}{|c|c|c|c|}
\hline Group & Phase & Factor & Source \\
\hline \multirow{5}{*}{$\begin{array}{l}\text { C1-RQ1: } \\
\text { Crucial factors }\end{array}$} & \multirow{5}{*}{ Pre-merger } & 1.1: Voluntary & $\begin{array}{l}\text { Ripoll \& De Miguel, } \\
2013 ; 2014\end{array}$ \\
\hline & & $\begin{array}{l}\text { 1.2: Horizontal and } \\
\text { complementary }\end{array}$ & $\begin{array}{l}\text { Ripoll \& De Miguel, } \\
\text { 2013; } 2014\end{array}$ \\
\hline & & 1.3: Small number & $\begin{array}{l}\text { Ripoll \& De Miguel, } \\
\text { 2013; } 2014 \\
\text { Gleibs, et al., } 2013\end{array}$ \\
\hline & & 1.4: Favourable context & $\begin{array}{l}\text { Ripoll \& De Miguel, } \\
\text { 2013; } 2014 \\
\text { Harman \& Harman, } 2003\end{array}$ \\
\hline & & 1.5: Decentralisation & Own sources \\
\hline \multirow{4}{*}{$\begin{array}{l}\text { C2-RQ2: } \\
\text { Best actions }\end{array}$} & \multirow{4}{*}{ Merger } & $\begin{array}{l}\text { 2.1: Synergies with } \\
\text { public authorities }\end{array}$ & $\begin{array}{l}\text { Hazelkorn, } 2007 \\
\text { Bennetot et al, } 2014 \\
\text { Walsh, } 2014\end{array}$ \\
\hline & & $\begin{array}{l}\text { 2.2: Precedence of } \\
\text { academic mission }\end{array}$ & $\begin{array}{l}\text { Slade et al., } 2016 \\
\text { Huisman, } 2008 \\
\text { Ylijoki, } 2014 \\
\text { Bennetot et al, } 2014\end{array}$ \\
\hline & & $\begin{array}{l}\text { 2.3: Other alternatives } \\
\text { explored }\end{array}$ & Bennetot et al, 2014 \\
\hline & & $\begin{array}{l}2.4: \text { Change } \\
\text { management } \\
\text { methodologies }\end{array}$ & $\begin{array}{l}\text { Lawlor, } 2013 \\
\text { Bennetot et al, } 2014\end{array}$ \\
\hline
\end{tabular}




\begin{tabular}{|c|c|c|c|}
\hline & & $\begin{array}{l}\text { 2.5: Internal } \\
\text { communication }\end{array}$ & $\begin{array}{l}\text { Evans, } 2015 \\
\text { Lawlor, } 2013 \\
\text { Bennetot et al, } 2014\end{array}$ \\
\hline & & $\begin{array}{l}\text { 2.6: External } \\
\text { communication }\end{array}$ & Bennetot et al, 2014 \\
\hline & & $\begin{array}{l}\text { 2.7: Connections with } \\
\text { industry }\end{array}$ & Own sources \\
\hline \multirow{5}{*}{$\begin{array}{l}\text { C3-RQ3: } \\
\text { Main } \\
\text { challenges }\end{array}$} & \multirow{5}{*}{ Post-merger } & $\begin{array}{l}\text { 3.1: Achieve a common } \\
\text { culture }\end{array}$ & $\begin{array}{l}\text { Puusa \& Kekäle, } 2015 \\
\text { Aspara et al., } 2014 \\
\text { Ripoll \& De Miguel, } \\
\text { 2013; } 2014\end{array}$ \\
\hline & & 3.2: Tackle bureaucracy & $\begin{array}{l}\text { Ripoll \& De Miguel, } \\
\text { 2013; } 2014 \\
\text { Mael, E. } 2014\end{array}$ \\
\hline & & $\begin{array}{l}\text { 3.3: To adjust existing } \\
\text { resources }\end{array}$ & $\begin{array}{l}\text { Johnes, } 2014 \\
\text { Hidalgo-Hidalgo } \\
\text { Valera, } 2016\end{array}$ \\
\hline & & $\begin{array}{l}\text { 3.4: To improve the } \\
\text { range of academic } \\
\text { courses on offer }\end{array}$ & $\begin{array}{l}\text { Hidalgo-Hidalgo } \\
\text { Valera, } 2016\end{array}$ \\
\hline & & $\begin{array}{l}\text { 3.5: To improve } \\
\text { international research } \\
\text { position }\end{array}$ & $\begin{array}{l}\text { Altbach, } 2015 \\
\text { Wangenge-Ouma, } 2010 \\
\text { Deschamps \& Lee, } 2014 \\
\text { Docampo et al., } 2015 \\
\text { Lee \& Park, } 2012\end{array}$ \\
\hline
\end{tabular}




\begin{tabular}{|c|c|c|c|}
\hline & & 3.6: Physical location & $\begin{array}{l}\text { Lawlor, } 2013 \\
\text { Frølich, N. et al., } 2016\end{array}$ \\
\hline \multirow{7}{*}{$\begin{array}{l}\text { C4-RQ4: } \\
\text { Post-merger } \\
\text { strategies }\end{array}$} & \multirow{7}{*}{ Post-merger } & $\begin{array}{l}\text { 4.1.a Size: big } \\
\text { 4.1.b Size: small }\end{array}$ & \multirow{7}{*}{ Own sources } \\
\hline & & 4.2 rankings & \\
\hline & & $\begin{array}{l}\text { 4.3.a support: public } \\
\text { 4.3.b support: private }\end{array}$ & \\
\hline & & 4.4.a funding: research & \\
\hline & & $\begin{array}{l}\text { 4.4.b funding: fund } \\
\text { raising } \\
\text { 4.4.c funding: real state }\end{array}$ & \\
\hline & & $\begin{array}{l}\text { 4.5.a orientation: city } \\
\text { 4.5.b orientation: } \\
\text { business }\end{array}$ & \\
\hline & & 4.6 new business model & \\
\hline
\end{tabular}


Table 3. Comparative analysis of the results

\begin{tabular}{|c|c|c|c|c|c|c|c|c|}
\hline & & & & $\mathrm{AU}$ & $\mathrm{CS}$ & $\mathrm{UL}$ & UM & US \\
\hline Group & & Phase & Type & t3 & $\mathrm{t} 2$ & t1 & t3 & t1 \\
\hline \multirow{6}{*}{$\begin{array}{l}\text { C1-RQ1: } \\
\text { factors }\end{array}$} & \multirow{5}{*}{ Crucial } & \multirow{5}{*}{ Pre-merger } & 1.1 & 0 & 1 & 1 & 1 & 1 \\
\hline & & & 1.2 & 1 & 1 & 1 & 1 & 1 \\
\hline & & & 1.3 & 1 & 1 & 1 & 1 & 0 \\
\hline & & & 1.4 & 1 & 0 & 0 & 1 & 0 \\
\hline & & & 1.5 & 0 & 0 & 1 & 0 & 0 \\
\hline & & & Total & 3 & 3 & 4 & 4 & 2 \\
\hline \multirow{7}{*}{$\begin{array}{l}\text { C2-RQ2: } \\
\text { actions }\end{array}$} & \multirow{7}{*}{ Best } & \multirow{7}{*}{ Merger } & 2.1 & 1 & 1 & 1 & 1 & 1 \\
\hline & & & 2.2 & 1 & 0 & 0 & 0 & 1 \\
\hline & & & 2.3 & 1 & 1 & 0 & 1 & 0 \\
\hline & & & 2.4 & 1 & 1 & 0 & 0 & 0 \\
\hline & & & 2.5 & 1 & 1 & 1 & 1 & 0 \\
\hline & & & 2.6 & 1 & 0 & 1 & 1 & 1 \\
\hline & & & 2.7 & 1 & 0 & 0 & 0 & 0 \\
\hline & & & Total & 7 & 4 & 3 & 3 & 2 \\
\hline \multirow{8}{*}{$\begin{array}{l}\text { C3-RQ3: } \\
\text { challenges }\end{array}$} & \multirow{6}{*}{ Main } & \multirow{6}{*}{ Post-merger } & 3.1 & 0 & 1 & 0 & 1 & 1 \\
\hline & & & 3.2 & 0 & 1 & 1 & 1 & 0 \\
\hline & & & 3.3 & 1 & 1 & 1 & 1 & 1 \\
\hline & & & 3.4 & 1 & 1 & 0 & 1 & 1 \\
\hline & & & 3.5 & 1 & 1 & 0 & 1 & 1 \\
\hline & & & 3.6 & 1 & 1 & 0 & 0 & 0 \\
\hline & & & Total: & 4 & 6 & 2 & 5 & 4 \\
\hline & & Post-merger & 4.1.a & 0 & 0 & 1 & 1 & 1 \\
\hline
\end{tabular}




\begin{tabular}{|l|l|l|l|l|l|l|l|}
\hline C4-RQ4: Post- & $4.1 . \mathrm{b}$ & 1 & 1 & 0 & 0 & 0 \\
\hline \multirow{3}{*}{ merger strategies } & 4.2 & 0 & 1 & 1 & 1 & 1 \\
\hline & $4.3 . \mathrm{a}$ & 1 & 1 & 0 & 0 & 1 \\
\hline & $4.3 . \mathrm{b}$ & 1 & 0 & 0 & 0 & 0 \\
\hline & $4.4 . \mathrm{a}$ & 0 & 0 & 0 & 0 & 0 \\
\hline & $4.4 . \mathrm{b}$ & 0 & 0 & 0 & 1 & 0 \\
\hline & $4.4 . \mathrm{c}$ & 0 & 0 & 1 & 0 & 0 \\
\hline & $4.5 . \mathrm{a}$ & 0 & 0 & 1 & 1 & 1 \\
\hline & $4.5 . \mathrm{b}$ & 0 & 0 & 0 & 0 & 0 \\
\hline & 4.6 & 1 & 1 & 0 & 0 & 0 \\
\hline & Total & 4 & 4 & 4 & 4 & 4 \\
\hline
\end{tabular}


Table 4. Comparative performance in the international ranking 2005-2015-2018

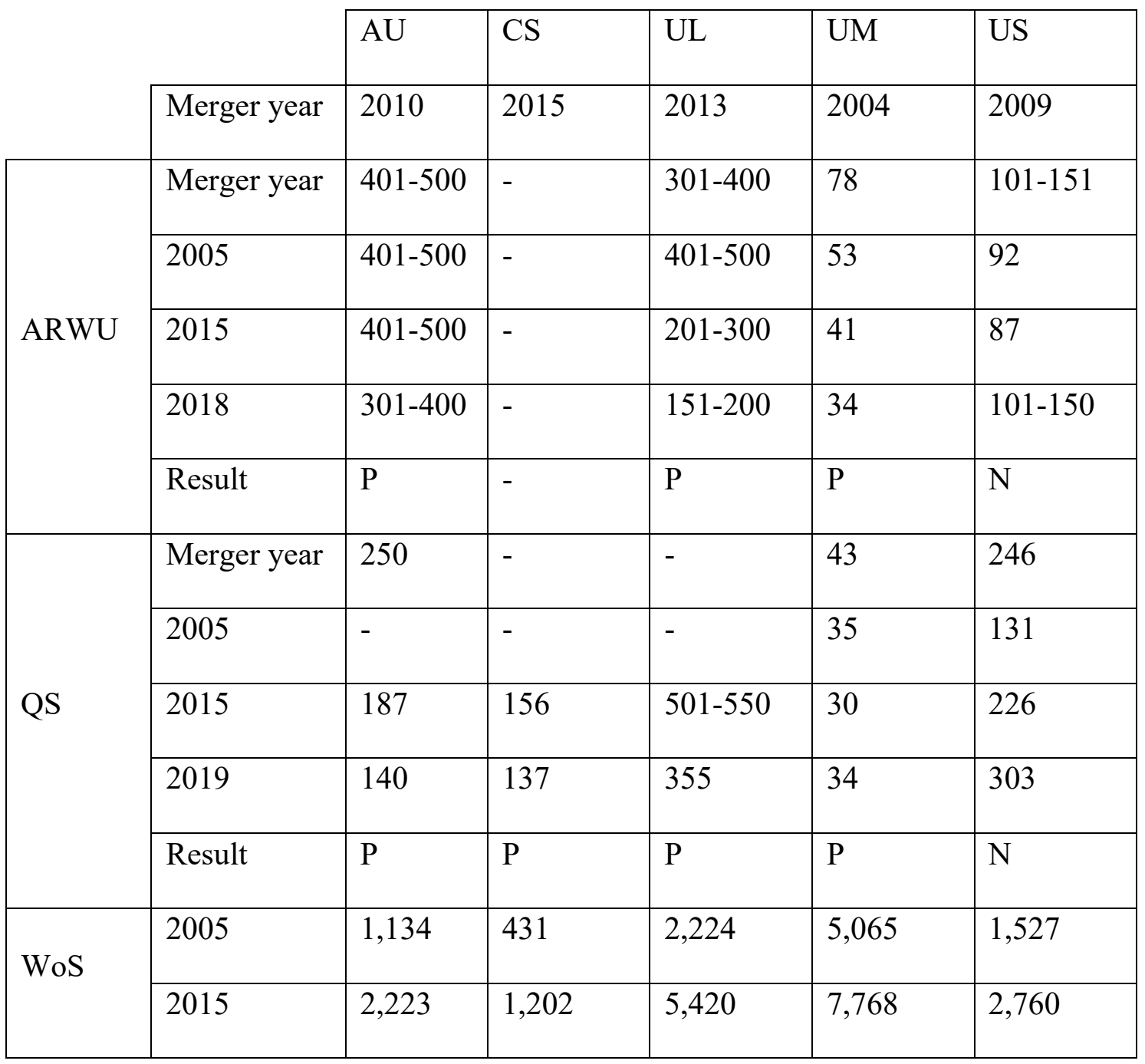

List of figures:

Figure 1. Paper network using Scopus Database and VOSviewer (Van Eck \& Waltman 2016).

Figure 2. Interview network using VOSviewer (Van Eck and Waltman 2016). 
